\title{
HIGH RESOLUTION STABLE ISOTOPE ANALYSIS OF A TASMANIAN SPELEOTHEM
}

\author{
by Jol M. Desmarchelier and Albert Goede
}

(with eight text-figures)

Desmarchelier, J.M. \& Goede, A., 1996 (30:vi): High resolution stable isotope analysis of a Tasmanian speleothem. Pap. Proc. R. Soc. Tasm. 130(1): 7-13. https://doi.org/10.26749/rstpp.130.1.41 ISSN 0080-4703. Department ofGeography and Environmental Studies, University ofTasmania, GPO Box 252C, Hobart, Tasmania, Australia 7001.

High resolution oxygen and carbon isotope analyses of part of a uniform diameter stalagmite from a cave in northern Tasmania have been used to study the climatic transitionfrom stadial to interstadial conditions during the early Last Glacial (109-95 ka). A significant change in oxygen isotope values suggests that temperature warmed rapidly by approximately $2^{\circ}-3^{\circ} \mathrm{C}$ between 100 and $97 \mathrm{ka}$. A decrease in carbon isotope values between 101 and $98 \mathrm{ka}$ indicates that moisture availability was increasing slightly in advance of rising remperature.

Key Words: Speleothem, stable isotope analysis, climatic change, Last Glacial, Tasmania, Australia.

\section{INTRODUCTION}

The aim of this study was to produce a high resolution record of the the stable isotope composition $\left({ }^{18} \mathrm{O} /{ }^{16} \mathrm{O}\right.$ and ${ }^{13} \mathrm{C} /{ }^{12} \mathrm{C}$ ) of the basal $600 \mathrm{~mm}$ of a $1420 \mathrm{~mm}$ tall, uniform diameter calcite stalagmite (LT) from Little Trimmer Cave in the Mole Creek karst region, northern Tasmania $\left(146^{\circ} 14^{\prime} 4^{\prime \prime} \mathrm{E}, 41^{\circ} 34^{\prime} 21^{\prime \prime} \mathrm{S}\right)$. The site is at an altitude of 460 $\mathrm{m}$ (fig. 1). A low resolution study had been done previously (Goede et al. 1986) but did not include interpretation of the basal $400 \mathrm{~mm}$ because of doubts that deposition had occurred under conditions of isotopic equilibrium. These doubts have been resolved by the present study (Desmarchelier 1994).

Uniform diameter stalagmites, when examined in longitudinal section, consist of a central core where vertical

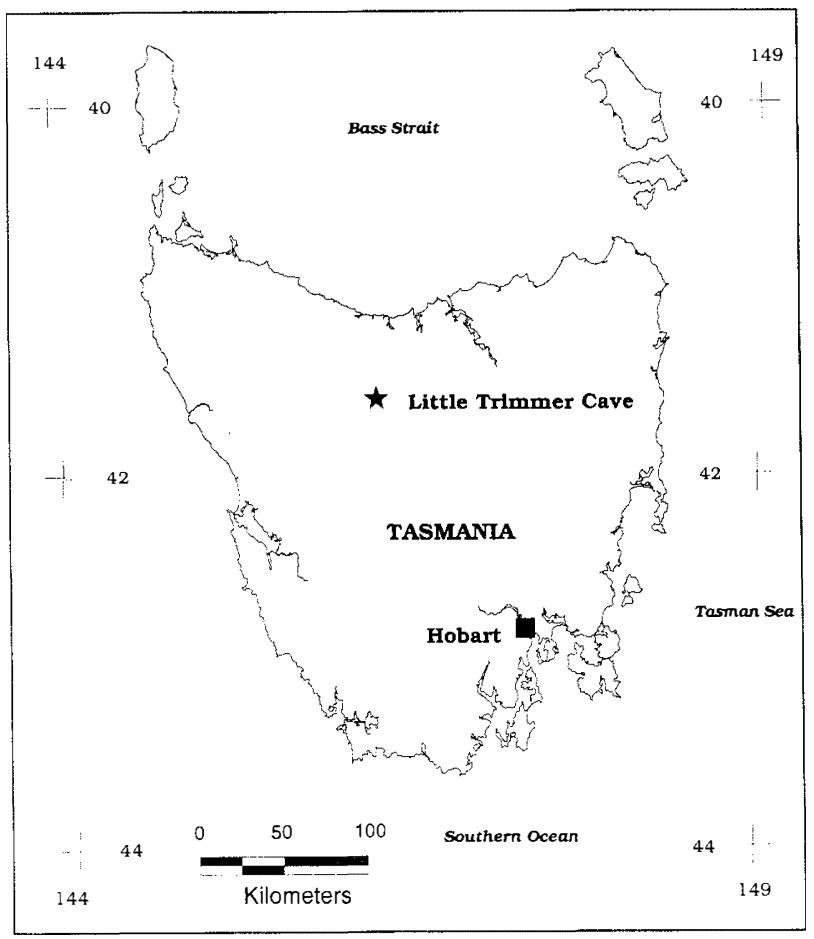

FIG. 1 - Map showing location of Little Trimmer Cave. accretion takes place on a subhorizontal surface, producing a sequence of convex upward layers surrounded by a narrow mantle formed by discontinuous deposition on a nearvertical outer surface (Goede 1994). Sampling was done at $5 \mathrm{~mm}$ intervals along the centre of the axis, using a dental drill with a $1.6 \mathrm{~mm}$ bit. In addition, in order to confirm conditions of isotopic equilibrium, seven samples were drilled from each of eight growth layers (Hendy \& Wilson 1968) but, following Talma \& Vogel (1992), sampling was restricted to the upper subhorizontal portion of each growth layer. Advances in sensitivity and automation of stable isotope mass spectrometers since the previous study of Goede et al. (1986) have enabled us to analyse a large number of samples with a much higher degree of measurement precision, while using much smaller quantities of calcite.

\section{GEOCHRONOLOGY}

Age determination of the speleothem (LT) is based on alpha particle analysis of seven samples spaced along its length. Four of these fall within the lowest $400 \mathrm{~mm}$ (fig. 2). Full analytical details are provided in Goede et al. (1986). The time scale used has been determined by linear regression analysis of heights above base against radiometric age estimates of all seven samples $(r=0.98)$. This technique minimises the random error: involved in individual age determinations (Goede \& Harmon 1983). The regression line indicates a growth rate of approximately $43 \mathrm{~mm} / \mathrm{ka}$. Samples at $5 \mathrm{~mm}$ intervals represent time intervals of approximately 116 years.

\section{NATURE OF STABLE ISOTOPES}

Measurement of variations in the iso topic ratios of ${ }^{18} \mathrm{O} /{ }^{16} \mathrm{O}$ and ${ }^{1.3} \mathrm{C} /{ }^{12} \mathrm{C}$ allows investigation of aspects of environmental conditions. Measurements are expressed as per mil (\%o) using the delta $(\delta)$ notation relative to the PDB (Peedee Belemnite) standard. The following subscripts are used throughout the text: $w$ - water, $c$ - calcite, $\mathrm{p}$ - precipitation and sw - seawater. 
${ }^{18} \mathrm{O} /{ }^{16} \mathrm{O}$ ratios can be used as indicators of palaeotemperatures provided that certain criteria are mer (Hendy 1971, Talma \& Vogel 1992). They are:

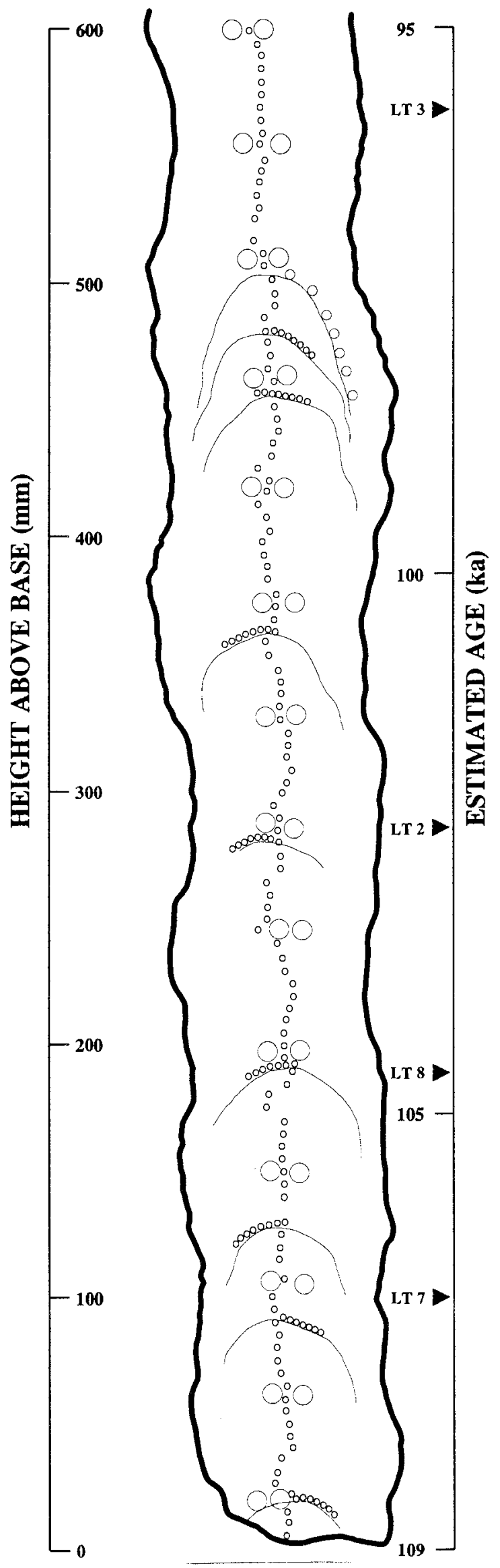

(1) the carbonate precipirate must have formed in isotopic equilibrium with the dripwater;

(2 the oxygen isotope content of the drip water must be estimated;

(3) no diagenetic alteration of the calcite must have occurred;

(4) the deposit must be datable.

Conditions conducive to isotopic equilibrium are nearconstant temperature conditions, humidicy close to $100 \%$, and little or no air movement. Such conditions are most likely to be found well away from cave entrances. Deposition of calcium carbonate under isotopic equilibrium conditions will occur only where there is a continuous supply of carbonate-saturated seepage water with a partial pressure of $\mathrm{CO}_{2}$ greater than that of the cave atmosphere.

Hendy \& Wilson (1968) suggested the following tests to confirm the existence of isotopic equilibrium.

(1) Paired measurements of $\delta^{18} \mathrm{O}$ and $\delta^{13} \mathrm{C}$ taken from the centre of the core along the vertical axis should show an absence of strong positive correlation.

(2) Paired measurements of $\delta^{18} \mathrm{O}$ and $\delta^{13} \mathrm{C}$ taken from a sequence of at least seven samples along an individual growth layer from the centre of the core outwards should not show a trend towards isotopically heavier values. This rest should be done for a number of growth layers.

Harmon et al.(1978) have proposed that the variations in oxygen isotope values in speleothems deposited under conditions of isotopic equilibrium are controlled by the three major factors noted below.

(1) Changes occur in the temperature of the depositional environment of the cave. The cave temperature usually approximates to the mean annual surface temperature and will respond to any fluctuations in the latter if climatic conditions change.

(2) Changes in the isotopic composition of seawater occur due to the accumulation of ${ }^{18} \mathrm{O}$ depleted glacial ice on land. They affect the isotopic composition of precipitation by a similar amount.

(3) Changes in the isotopic composition of precipitation are also caused by temperature and humidity changes at sites of evaporation and precipitation, as well as possible changes in the geographical location of moisture source areas.

Goede et al. (1986) discussed these factors, noting that factors (1) and (2) cause secondary calcite deposited during cold periods to become enriched in ${ }^{18} \mathrm{O}$, whereas factor (3) has the opposite effect. Harmon et al.(1978) noted that the majority of stalagmites examined by them showed a negative relationship berween $\delta^{18} \mathrm{O}$ values of calcite and palaeotemperatures. In contrast, stalagmites from Vancouver Island, Norway and Tasmania, all areas subject to a temperate maritime west coast climate, show a positive relationship between $\delta^{18} \mathrm{O}$ values of calcite and palaeotemperatures (Gascoyne et al. 1980, 1981, Goede et al.1986, 1990, Lauritzen et al.1990). This indicates that, in these areas, factor (3) is dominant in determining the isotopic ratio of speleothem calcite.

FIG. 2 - Longitudinal section of basal $600 \mathrm{~mm}$ of LT stalagmite examined in this study. Median positions of uranium series dates are indicated along the estimated age scale. Concave upward lines represent prominent growth horizons. Large and medium-size circles indicate sampling by Goede et al. (1986). Small circles indicate high resolution sampling for this study. Sets of samples were taken along growth lines to establish deposition under conditions of isotopic equilibrium. 
Seasonal variation in the isotopic composition of precipitation will not affect seepage waters because soil water is homogenised, causing cave drip water to maintain a near-constant isotopic composition. Goede \& Hitchman (1984) and Goede et al. $(1986,1990)$ have shown that, in Tasmania, the isotopic composition at present is best related to the weighted mean value of winter precipitation. This implies that summer precipitation in Tasmania does not contribute significantly to the supply of seepage water. Therefore, the $\delta^{18} \mathrm{O}$ values of contemporary Tasmanian speleothems reflect predominantly changes in winter temperatures rather than mean annual temperatures (Goede 1994). This may not always have been true in the past under conditions of wetter and cooler summers.

Variations in $\delta^{13} \mathrm{C}$ values in speleothems, unlike $\delta^{18} \mathrm{O}$ values, are not related to palaeotemperature. Values are either unrelated or only weakly correlated with the oxygen isotope values. Secular variations in carbon isorope values indicate that they contain palaeoenvironmental information but, until recently, interpretation has been contentious. In recent years, research relevant to this problem has been done not only on speleothems (Brooke et al. 1990, Dorale et al. 1992, Talma \& Vogel 1992) but has also included studies of soil carbonates (Cerling et al.1989, Quade \& Cerling 1990, Quade, Cerling \& Bowman 1989a, b) as well as sub-aqueous wall crust in a karst spring (Coplen et al.1994).

The relevant literature is discussed by Goede et al. (in press), who conclude that, in temperate environments, changes in $\delta^{13} \mathrm{C}$ over time reflect predominantly temporal changes in plant activity, with a minor influence due to natural changes in the isoropic composition of $\mathrm{CO}_{2}$, at least until the beginning of the industrial revolution (Baskaran \& Krishnamurthy 1993, Marino et al. 1992). Carbon isotope values are also affected slightly by the composition of the limestone, but this effect is assumed to remain constant during the growth period of a stalagmite. In cool temperate climates, such as are found in Tasmania, plant activity is likely to be controlled by temporal variations in summer insolation and moisture availability.

\section{TESTS FOR ISOTOPIC EQUILIBRIUM}

The first test suggested by Hendy \& Wilson (1968) involves the degree of positive correlation between $\delta^{18} \mathrm{O}$ and $\delta^{13} \mathrm{C}$ values of samples taken along the longitudinal axis. A weak but statistically significant negative correlation was found $(\mathrm{r}=-0.40, \mathrm{n}=119, \mathrm{p}<0.001)$, confirming deposition under conditions of isotopic equilibrium (fig. 3 ).

The second test involves examination of sets of seven samples from each of eight growth layers. The position of the samples is illustrated in figure 2 . These sets show no significant correlation beween paired $\delta^{18} \mathrm{O}$ and $\delta^{13} \mathrm{C}$ values, with one exception where the changes are relatively small. Overall the evidence is strongly in favour of deposition under isotopic equilibrium conditions.

\section{PREVIOUS ANALYSIS}

The stalagmite was analysed previously by Goede et al. (1986) who used a $5 \mathrm{~mm}$ masonry drill to sample at intervals of $45 \mathrm{~mm}$. Three growth layers were also sampled to establish deposition under equilibrium conditions. The basal

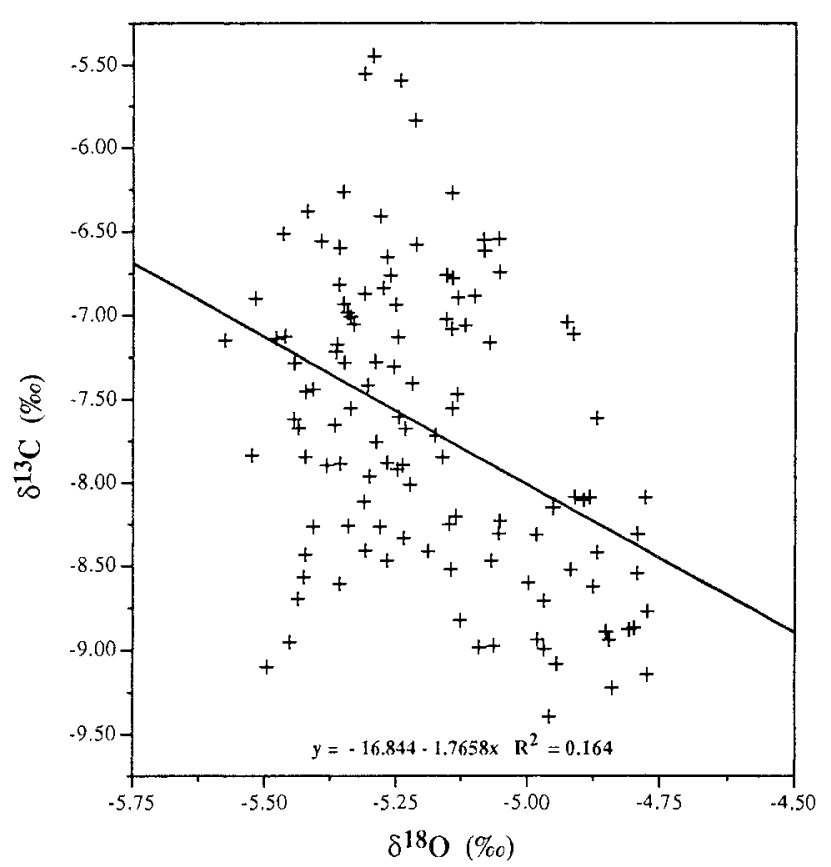

FIG. 3 - Scattergram of $119 \delta^{18} \mathrm{O}$ and $\delta^{13} \mathrm{C}$ values of samples taken from the long axis of the $L T$ stalagmite. The regression line is shown.

$400 \mathrm{~mm}$ was not interprered as a palaeotemperature record, because of doubts about equilibrium deposition. The results of isotopic analyses done in the previous study are given in figure 4 . The present-day isotopic composition of speleothem material was determined by multiple analyses of calcite removed from two plastic funnels used to collect dripwater during 1979. The values obtained were $\delta^{18} \mathrm{O}=-3.75$ and $\delta^{13} \mathrm{C}=-12.21 \%$ PDB.

In an earlier paper dealing with the LT stalagmite, palaeotemperature estimates were obrained by measuring $\delta \mathrm{D}_{\mathrm{w}}$ values of fluid inclusions (Goede et al. 1986). The relationship berween $\delta \mathrm{D}_{\mathrm{p}}$ and $\delta^{18} \mathrm{O}_{\mathrm{p}}$ established by monthly sampling for one year near the cave entrance was used to estimate corresponding values of $\delta^{18} \mathrm{O}$ at the time of deposition of the stalagmite. These values, in turn, were used to calculate palaeotemperatures. The problem with this approach is that it does not give a unique outcome, since the intercept

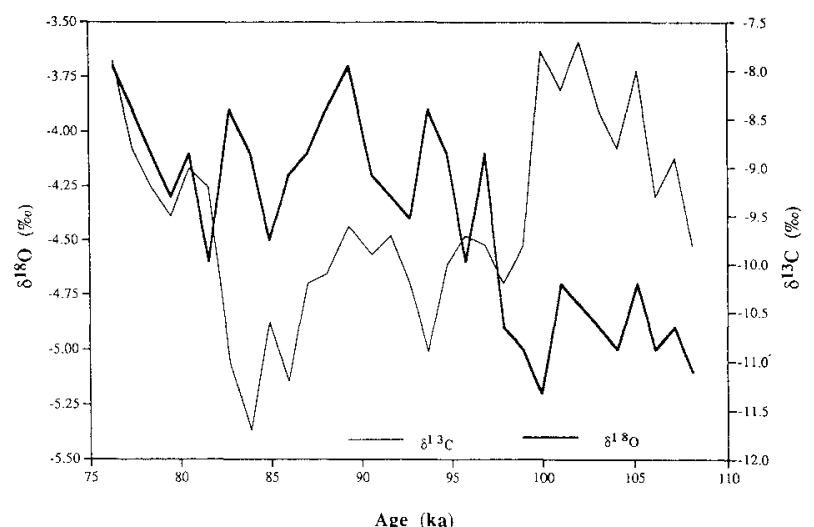

FIG. 4 - Temporal variations in the values of $\delta^{18} \mathrm{O}$ and $\delta^{13} \mathrm{C}$ obtained by interval sampling of the whole of the Little Trimmer stalagmite in an earlier study (Goede et al. 1986). 
in the relationship between $\delta \mathrm{D}_{\mathrm{w}}$ and $\delta^{18} \mathrm{O}_{\mathrm{w}}$, known as the deuterium excess $\left(d_{0}\right)$, is known to have varied over time. In Antarctica, values of $\mathrm{d}_{\mathrm{o}}$ have been found to range from 8.3 to 4 over the last glacial-interglacial hemicycle (Jouzel et al. 1982). In Tasmania the deuterium excess is unlikely to have remained constant over time, but the amount of variation is not known.

A different approach, first suggested by Gascoyne et al. $(1980,1981)$, is used here. It is particularly appropriate for areas where the oxygen isotope composition of calcite has a positive relationship with temperature $\left(\mathrm{d} \delta^{18} \mathrm{O} / \mathrm{dT}>0\right)$. It relies on the supposition that the value of $\delta^{18} \mathrm{O}_{c}$ changes in response to three factors:

(1) Changes in cave temperature; at $10^{\circ} \mathrm{C}$, the fractionation effect for $\delta^{18} \mathrm{O}_{\mathrm{c}}=-0.24 \% 0 /{ }^{\circ} \mathrm{C}$ (Epstein et al. 1951).

(2) Changes in isotopic composition of precipitation due to changes in the isotopic composition of seawater resulting from variations in the amount of glacial ice on land. Shackleton \& Opdyke (1973) estimated that, under full glacial conditions, the value for seawater was $1.20 \%$ higher than at present. To calculate the effect for a $1^{\circ} \mathrm{C}$ change in temperature requires an estimate of the amount of temperature lowering in the area during the last glacial maximum. Hannan (1989) used the extent of glacial ice in the Mersey Valley, close to the cave site, to estimate a lowering of mean annual temperature of $6.2^{\circ} \mathrm{C}$. This suggests a change in the oxygen isotope composition of $-0.2 \%$ for a $1{ }^{\circ} \mathrm{C}$ rise in temperature.

(3) In some areas, there is a strong positive relationship between the oxygen isotope composition of precipitation and temperature. Gascoyne et al. (1980) suggested that this is due to a change in temperature gradient between the site of evaporation and the site of precipitation. Recent work suggests that the reasons are more complex (Grootes 1993, Rozanski et al. 1993). The magnitude of this factor has been determined as $0.7 \% 0 /{ }^{\circ} \mathrm{C}$ for oceanic precipitation sites (Dansgaard 1964, Lauritzen et al. 1990).

Gascoyne et al. $(1980,1981)$ summarised the relationship as follows:

$$
\Delta \delta^{18} \mathrm{O}_{\mathrm{c}}=\mathrm{d} \Delta_{\mathrm{c}-\mathrm{w}} / \mathrm{dT}+\Delta \delta^{18} \mathrm{O}_{\mathrm{sw}}+\left(\mathrm{d} \delta^{18} \mathrm{O}_{\mathrm{p}} / \mathrm{dT}\right) \Delta \mathrm{c}
$$

For a $1{ }^{\circ} \mathrm{C}$ lowering in temperature, $\Delta \delta^{18} \mathrm{O}_{\mathrm{c}}=-2.6 \%$.

Since the present-day oxygen isotope composition of calcite is known, temperature at time $T_{t}$ can be estimated from the following expression:

$$
\mathrm{T}_{\mathrm{t}}=9.5+\left(\delta^{18} \mathrm{O}_{\mathrm{c}}+3.75\right) / 0.26
$$

This expression has been used to calculate the palaeotemperature estimates shown in figure 5.

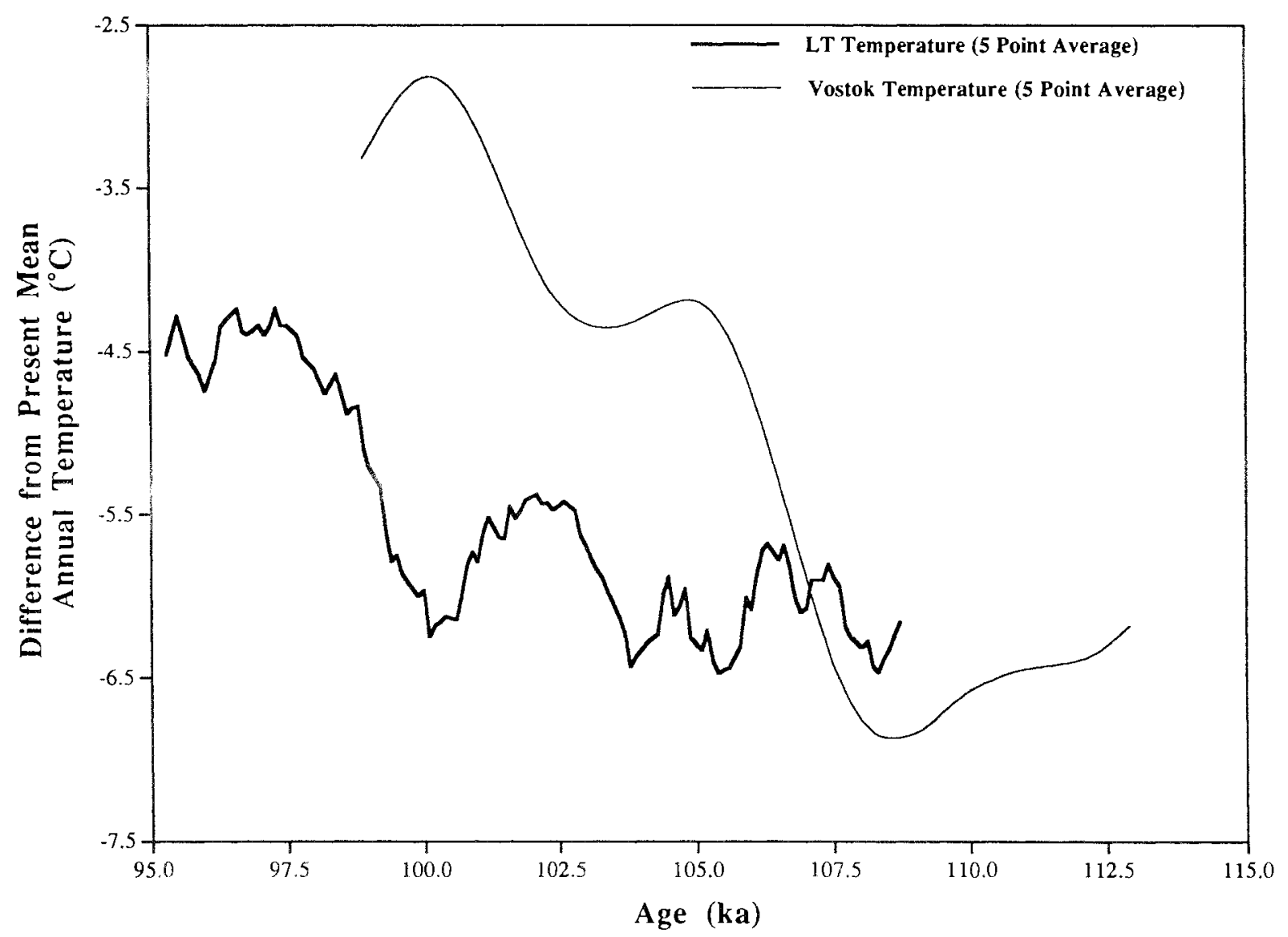

FIG. 5 - Five-year running mean of temperature deviation from the present mean annual temperature of $9.5^{\circ} \mathrm{C}$ for the $L T$ isotope record compared with the temperature difference record for Vostok where present mean annual temperature is $-55.5^{\circ} \mathrm{C}$ (Lorius et al. 1985). 


\section{DISCUSSION AND RESULTS}

\section{Oxygen Isotope Record}

The $\delta^{18} \mathrm{O}$ values and the five-year running means have been plotted against the estimate age in figure 6 . The most significant change occurs between $100 \mathrm{ka}$ and $97 \mathrm{ka}$, where values rise from $-5.4 \%$ to $-4.8 \%$ corresponding to a warming of approximately $2^{\circ} \mathrm{C}$. In figure 5 departures from the present mean annual temperature of $9.5^{\circ} \mathrm{C}$ are shown. They have been calculated using equation 2 (above). In the same diagram, the smoothed temperature record from the Vostok ice core is also shown (Jouzel et al. 1987).

Figures 5 and 6 suggest that warming, equivalent in time to the transition between marine isotope stages $5 \mathrm{~d}$ and $5 \mathrm{c}$, occurred in two steps. A similar pattern can also be seen in the Vostok record where a similar stepped temperature rise occurred at approximately the same rime. The 3000-year timeshift required to match the two sets of records is easily explained by the limitations of daring. The Vostok record shows a greater temperature rise $\left(4^{\circ} \mathrm{C}\right)$ during the transition from $5 \mathrm{~d}$ to 5 c compared with the LT record $\left(2^{\circ} \mathrm{C}\right)$. However, following the rise, temperature estimates for the amount of temperature lowering during stage $5 \mathrm{c}$ are very similar.

The Vostok record is dominated by a $100 \mathrm{ka}$ glacialinterglacial oscillation with a temperature amplitude of about $6^{\circ} \mathrm{C}$ (Lorius et al. 1985 , Jouzel et al. 1987). The stages in the Vostok record are identified by capital letters, commencing with A for the Holocene epoch. Vostok stage $\mathrm{E}$ is an interstadial, characterised by two well-defined temperature maxima at approximately 100 and $81 \mathrm{ka}$, as well as some minor oscillations. The earlier maximum appears to match the maximum at $97 \mathrm{ka}$ in the LT record. A slight difference in timing is to be expected, due to limitations in the accuracy of dating in both records. The recent development of uranium series mass spectrometry (TIMS) dating and its successful application to speleothems means that dating precision can be improved substantially (Lundberg \& Ford 1994).

\section{Carbon Isotope Record}

The $\delta^{13} \mathrm{C}$ isotope record is shown in figure 7 . There is a fluctuating upward trend from $109 \mathrm{ka}$ until a maximum value of $-6.0 \%$ is reached at $101 \mathrm{ka}$. Between 101 and 98 ka values fall rapidly to $-9.0 \%$. A slight upward trend follows until the record terminates at $95 \mathrm{ka}$.

It has been argued that, in cool, temperate climates, carbon isotope variations may be interpreted largely in terms of variations in plant activity, with more negative values indicating higher levels of activity (Goede et al. in press). Change in the atmospheric composition of atmospheric $\mathrm{CO}_{2}$, due ro secular variation, can be expected to have made a minor contribution - at least in preindustrial times.

In the Tasmanian environment, plant activity is seasonal and strongly influenced by available moisture, which can be expected to be at least partly modulated by variations in summer insulation. Some evidence has already been detected that variations in $\delta^{13} \mathrm{C}$ in speleothems from Tasmania and eastern Victoria are affected by summer insolation. Goede (1994) published a speleothem record from the Florentine Valley in south central Tasmania, covering a period from 98 to $55 \mathrm{ka}$. The carbon isotope record shows two prominent peaks of isotopically heavy carbon at approximately 95 and $75 \mathrm{ka}$ and troughs of isotopically light values at 85 and $60 \mathrm{ka}$. Mid-month insolation data for December at $30^{\circ} \mathrm{S}$ (Berger \& Loutre 1991) show radiation maxima at $95 \mathrm{ka}$ $\left(531 \mathrm{~W} / \mathrm{m}^{2}\right)$ and $72 \mathrm{ka}\left(510 \mathrm{~W} / \mathrm{m}^{2}\right)$ and radiation minima at $84 \mathrm{ka}\left(462 \mathrm{~W} / \mathrm{m}^{2}\right)$ and $61 \mathrm{ka}\left(472 \mathrm{~W} / \mathrm{m}^{2}\right)$. A short isotopic record (13.4 to $10.6 \mathrm{ka}$ ) from Buchan, eastern Victoria, shows a trough of isotopically light carbon isotope values at $11.2 \mathrm{ka}$ closely following a December insolation minimum at $12.5 \mathrm{ka}\left(474 \mathrm{~W} / \mathrm{m}^{2}\right)$ (Goede et al. in press).

Summer insolation minima coincide with wincer insolation maxima with a change of similar percentage magnitude. It appears that, in southeastern Australia, conditions for maximum plant productivity coincide with conditions of minimum summer radiation which are also times of minimum seasonal variation. The radiation curve of Berger \& Loutre (1991) for the time period examined in this study is of particular interest, because the summer insolation minimum that occurred at $106 \mathrm{ka}$ (mid-month December value of $449 \mathrm{~W} / \mathrm{m}^{2}$ ) is the lowest of any values calculated for the Late Pleistocene and Holocene.

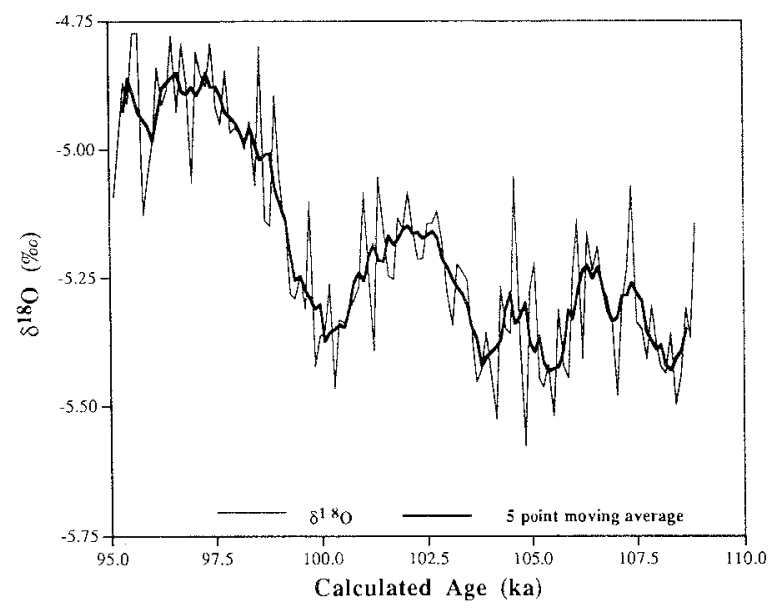

FIG. 6-Oxygen isotope data plotted against age together with the five-year running mean.

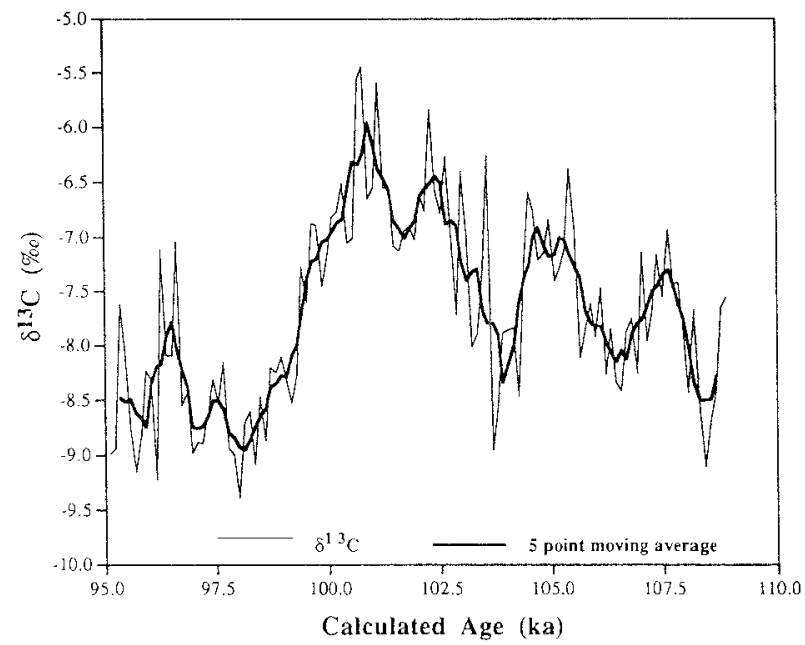

FIG. 7 - Carbon isotope data plotted against age together with the five-year running mean. 
In order to test the hypothesis that strongly negative values of $\delta^{13} \mathrm{C}$ tend to coincide with summer radiation minima, the $\delta^{13} \mathrm{C}$ values for the LT stalagmite have been plotted on the same time scale as the solar radiation curve for $30^{\circ} \mathrm{S}$ (fig. 8). Agreement between the two curves is poor, but this may be due to the limited accuracy and precision of the early alpha spectrometry dates on which the age scale is based (Goede et al. 1986). Until such time as more precise mass spectrometric uranium series dates can be obtained, the hypothesis cannot be adequately tested.

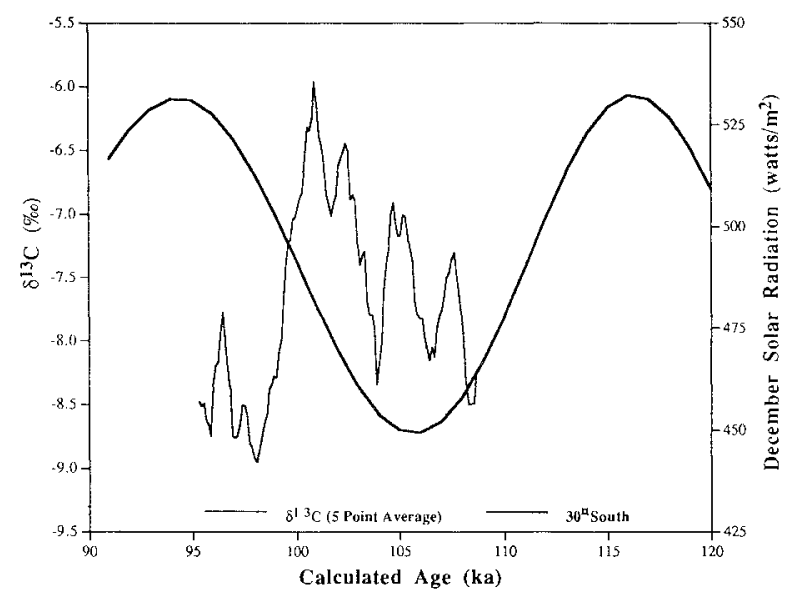

FIG. 8- Temporal variations in the carbon isotope values compared with fluctuations in solar radiation received for December at $30^{\circ} \mathrm{S}$ (Berger of Loutre 1991).

\section{CONCLUSIONS}

The high resolution isotope record of the basal $600 \mathrm{~mm}$ of the LT stalagmite provides a detailed record of local mean winter temperature change for a period corresponding to the transition from marine isotope sub-stage $5 \mathrm{~d}$ to $5 \mathrm{c}$. It indicates a warming of some $2^{\circ} \mathrm{C}$ in two phases over a period of some 5000 years, with most of the warming taking place between 100 and $98 \mathrm{ka}$. The record compares well with that from the Vostok core, if allowance is made for minor discrepancies in age determination. The major difference between the two is that the Vostok record indicates a mean annual temperature rise of $4^{\circ} \mathrm{C}$, with most of it taking place during the first warming phase.

The difference between the two records may be due to the likelihood that the LT speleothem reflects predominantly changes in mean winter temperature, while the Vostok record provides a proxy for mean annual temperature. This is supported by the fact that winter insolation at $30^{\circ} \mathrm{S}$ during this time is declining rapidly, with midmonth insolation for June reaching $199 \mathrm{~W} / \mathrm{m}^{2}$ at $95 \mathrm{ka}$ (Berger \& Loutre 1991).

The carbon isotope record at this stage does not support evidence from two other speleothem records from Tasmania and Victoria, that isotopically light carbon isotope values tend to coincide with summer radiation minima. Uranium series MS dating will be required to clarify the relationship. The $\delta^{13} \mathrm{C}$ values reached a peak at about $101 \mathrm{ka}$, indicating a low level of plant activity. They then fell rapidly to a minimum at $98 \mathrm{ka}$, presumably in response to rising plant activity. The beginning of this trend predated the beginning of a rapid temperature rise at $100 \mathrm{ka}$. -

\section{ACKNOWLEDGEMENTS}

We are grateful to Mike Power and Christina Cooke of the Central Science Laboratory at the University of Tasmania for carrying out the stable isotope analyses. Uranium series age determinations by alpha particle spectrometry wete made by Dr Russell Harmon, who co-authored an earlier paper on the stalagmite.

\section{REFERENCES}

BASKaran, M. \& Krishnamurthy, R.V., 1993: Speleothems as proxy for the carbon isotope composition of atmospheric $\mathrm{CO}_{2}$. Geophys. Res. Lett. 20 (24): 2905-2908.

Berger, A. \& LoUTRE, M.F., 1991: Insolation values for the climate of the last 10 million years. Quat. Sci. Rev. 10: $297-317$.

Brooke, G.A., Burney, D.A. \& Cowart, J.B., 1990: Desert palacoenvironmental data from cave speleothems with examples from the Chihuahuan, Somali, Chabli and Kalahari deserts. Palaeogeogr., Palaeoclimat., Palaeoecol. 76: 311-329.

Cerling, T.E., Quade, J., Wang, Y. \& Bowman, J.R., 1989: Carbon isotopes in soils and palaeosols as ecology and palaeoecology indicators. Nature 34: 138-139.

Coplen, T.B., Winograd, I.J., Landwehr, J.M. \& Riggs, A.C., 1994: 500,000-Year stable carbon isotope record from Devils Hole, Nevada. Science 263: 361-365.

Dansgand, W., 1964: Stable isotopes in precipitation. Tellus 16: $436-468$.

DesmarCHELIER, J.M., 1994: An isotopic analysis of a Tasmanian speleothem. Unpub. BSc Hons thesis, Geogr. Environ. Stud. Dep., Univ. Tasm.: 129 pp.

Dorale, J.A., Gonzalez, L.A., Reagan, M.K., PicketT, D.A., Murrell, M.T. \& Baker, R.G., 1992: A high resolution record of Holocene climatic change in speleothem calcite from Cold Water Cave, NE Iowa. Science 258: 16261630 .

Eisteln, S., Buchsbaum, R., Lowenstam, H. \& Urey, H.C., 195I: Carbonate-water isotopic scale. Geol. Soc. Am. Bull. 62: 417-426.

Gascoyne, M., Schwarcz, H.P. \& Ford, D.C., 1980: A palaeotemperature curve for the Mid-Wisconsin in Vancouver Island. Nature 285: 274--275.

Gascoyne, M., Ford, D.C. \& Schwarcz, H.P., 1981: Late Pleistocene chronology and palaeoclimate of Vancouver Island determined from cave deposits. Can. J. Earth Sci. 18: 1643-1652.

Goede, A., 1994: Continuous Early Last Glacial palaeoenvironmental record from a Tasmanian speleothem based on stable isotope and minor element variations. Quat. Sci. Rev. 13: 283-291.

Goede, A. \& Harmon, R.S., 1983: Radiometric dating of Tasmanian speleothems - evidence of cave evolution and climatic change. J. Geol. Soc. Aust. 30: 89-100.

Goede, A. \& Hitchiman, M.A., 1984: Late Quaternary dimatic change: evidence from a Tasmanian speleothem. In Vogel, J.C. (Ed.): LATE CAINOZOIC PALAEOCLIMATES OF THE SOUTHERN HEMISPHERE. Balkema, Rotterdam: 221-232.

Goede, A., Green, D.C. \& Harmon, R.S., 1986: Late Pleistocene palatotemperature record from a Tasmanian speleothem. Aust. J. Earth Sci. 33: 333-342. 
Goede, A., Veeh, H.H. \& Ayluffe, L.K., 1990: Late Quaternary palaeotemperature records for two Tasmanian speleothems. Aust. J. Earth Sci. 37: 267-278.

Goede, A., McDermott, F., Hawkesworth, C., Webb, J. \& Finlayson, B., in press: Evidence of Younger Dryas and Neoglacial cooling in a late Quaternary palaeotemperature record from a speleothem in eastern Victoria, Australia. J. Quat. Sci.

Grootes, P.M., 1993: Interpreting continental oxygen isocope records. In Swart, P.K., Lohmann, K.C., McKenzie, J.A. \& Savin, S.M. (Eds): CHANGE AND CONTINENTAL ISOTOPIC RECORDS. Am. Geophys. Mon. 78: 37-46.

Hannon, D.G., 1989: The glacial history of the upper Mersey Valley. Unpubl. MSc thesis, Dep. Geogr., Univ. Tasm.: $164 \mathrm{pp}$.

Harmon, R.S., Thompson, P., Schimarcz, H.P. \& Ford, D.C., 1978: Late Pleistocene palaeoclimates of North America as inferred from stable isotope studies of speleothems. Quat. Res. 9: 54-70.

HENDY, C.H., 1971: The isotopic geochemistry of speleothems - 1. Geochim. Cosmochim. Acta 35: 801-824.

Hendy, C.H. \& WiLson, A.T., 1968: Palaeoclimatic data from speleothems. Nature 219:48-51.

Jouzel, J., Lorius, C., Petit, J.R., Genthon, C., Barkov, N.I., Kotlyakov, V.M. \& Petrov, V.M., 1987: Vostok ice core: a continuous isotope temperature record over the last climatic cycle (160 000 years). Nature 329: 403407.

Jouzel, J., Melivat, L. \& Lorius, C., 1982: Deuterium excess in an East Antarctic ice core suggests higher relative humidicy at the oceanic surface during the last glacial maximum. Nature 229: 688-691.

Lauritzen, S.-E., Lovlie, R., Moe, D. \& Ostbye, E., I990: Paleoclimate deduced from a multidisciplinary study of a half-million-year-old sralagmite from Rana, northern Norway. Quat. Res. 34: 306-316.

lorius, L., Jouzel, J., Ritz, C., Merlivat, L., Barkov, N. I., KorotKeVICH, Y.S. \& Kotlyakov, V.M., 1985: A
150000 -year climaric record from Antarctic ice. Nature 316:591-596.

Lundberg, J. \& Ford, D.C., 1994: Late Pleistocene sealevel change in the Bahamas from mass specrromerric U-series dating of submerged speleothem. Quat. Sci. Rev. 13:114.

Marino, B.D., McElroy, M.B., Salawitch, R.J. \& Spaulding, W.G., 1992: Glacial-to-interglacial variations in the carbon isotopic composirion of atmospheric $\mathrm{CO}_{2}$. Nature 357: 461-465.

Quade, J. \& Cerling, T.E. 1990: Stable isotopic evidence for a pedogenic origin of carbonates in trench 14 near Yucca Mountain, Nevada. Science 250: 1549-1552.

Quade, J., Cerrling, T.E. \& Bowman, J.R., 1989a: Development of Asian monsoon revealed by marked ecological shift during the latest Miocene in northern Pakistan. Nature 342: $163-166$

Quade, J., Cerling, T.E. \& Bowman, J.R., 1989b: Systematic variations in the carbon and oxygen isotopic compositions of pedogenic carbonate along elevation transects in the Southern Great Basin, United States. Geol. Soc. Am Bull. 101: 464-475.

Rozanski, K., Araguas-Araguas, L. \& Gonfiantini, R., 1993 Isotopic patterns in global precipitation. In Swart, P.K. Lohmann, K.C., McKenzie, J.A. \& Savin, S.M. (Eds): CLIMATE CHANGE AND CONTINENTAL ISOTOPIC RECORDS. Am. Geophys. Mon. 78: 1-36.

Shackleton, N.J. \& Opdyke, N.D., 1973: Oxygen isotope and palaeomagnetic stratigraphy of equatorial Pacific core V28-238: oxygen isotope temperatures and ice volumes on $10^{5}$ and $10^{6}$ year scale. Quat. Res. 3: 39-55.

TAlma, A.S. \& Vogel, J.C., 1992: Late Quaternary palaeotemperatures derived from a speleothem from Cango Caves, Cape Province, South Africa. Quat. Res. 37: 203-213.

(accepted 17 October 1995) 
